\title{
Impact of attending a health care conference in Toronto during the severe acute respiratory syndrome crisis: Survey of delegates
}

\author{
Jennifer Stinson RN MSc ${ }^{1}$, Colin JL McCartney MBChB FRCA FFARCSI ${ }^{2}$, \\ Andrea Leung $\mathrm{BSc}^{2}$, Joel Katz $\mathrm{PhD}^{2,3,4,5}$
}

\begin{abstract}
J Stinson, CJL McCartney, A Leung, J Katz. Impact of attending a health care conference in Toronto during the severe acute respiratory syndrome crisis: Survey of delegates. Pain Res Manage 2004;9(3):137-143.
\end{abstract}

OBJECTIVE: To describe the impact on delegates of attending the Canadian Pain Society's annual meeting in Toronto during the severe acute respiratory syndrome (SARS) crisis in May 2003.

METHODS: A prospective survey design was used. Surveys were sent to all delegates $(n=432)$ who attended the conference, and 294 delegates responded (68\% response rate). The survey was developed to determine the level of concern about travelling to Toronto; the adequacy of screening measures; the level of stress about attending; and the occupational consequences of attending.

RESULTS: Fifty per cent of the participants were not concerned about travelling to Toronto, while the other $50 \%$ expressed some concern ranging from mild to serious. Concerns included being exposed to SARS and fear of transmitting it to others upon return. Reasons for attending the conference despite concern included a desire for continuing education, decrease in the number of reported SARS cases, and perceived minimal risk. Almost one-half $(n=140)$ felt the screening measures at the conference were adequate, while $4 \%$ felt they were inadequate and $9 \%$ somewhat adequate. Delegates $(n=99)$ suggested that temperature-taking $(32.2 \%)$, improved screening vigilance $(14.4 \%)$, SARS screening forms checked daily $(9.1 \%)$, strictly controlled entry $(8.1 \%)$ and adopting hospital screening procedures $(7.1 \%)$ should have been instituted.

CONCLUSION: Health care professionals planning conferences in this era of new respiratory diseases can benefit from understanding the responses of delegates who attended conferences during outbreaks. Clear communication about the potential risks and benefits, as well as instituting full screening precautions, will help to allay concerns.

Key Words: Health care conference; Severe acute respiratory syndrome; Survey
Tenue d'un congrès sur les soins de santé, à Toronto, durant la crise du syndrome respiratoire aigu sévère : enquête auprès des participants

OBJECTIF : Décrire l'influence que la tenue du congrès annuel de la Société canadienne pour le traitement de la douleur, durant la crise du syndrome respiratoire aigu sévère (SRAS), en mai 2003, à Toronto, a eu sur les participants.

MÉTHODE : Nous avons eu recours à une conception d'enquête prospective. Le questionnaire a été envoyé à toutes les personnes $(n=432)$ qui ont participé au congrès et 294 d'entre elles ont répondu au sondage (taux de réponse : $68 \%$ ). L'enquête a été conçue de manière à déterminer le degré d'inquiétude des participants devant le fait de devoir se rendre à Toronto, le caractère adéquat des mesures de dépistage, le degré de stress suscité par la participation au congrès et les conséquences pour le travail. RÉSULTATS : Cinquante pour cent des participants se sont dits non préoccupés par le fait de devoir se rendre à Toronto, tandis que les autres ont exprimé une certaine crainte, dont le degré variait de faible à élevé. Parmi les objets d'appréhension figuraient les risques d'exposition au SRAS et de transmission de la maladie à d'autres personnes au retour. Quant aux motifs pour participer au congrès malgré les craintes, mentionnons le désir de formation continue, la diminution du nombre de cas déclarés et la perception de risque minime. Presque $50 \%(n=140)$ des répondants ont jugé les mesures de dépistage adéquates, tandis que $4 \%$ les ont jugées inadéquates et $9 \%$, quelque peu adéquates. Des répondants ( $\mathrm{n}=99)$ ont indiqué que certaines mesures auraient dû être appliquées, par exemple la prise de température $(32,2 \%)$, une vigilance accrue à l'égard du dépistage $(14,4 \%)$, des formules de dépistage du SRAS vérifiées tous les jours $(9,1 \%)$, un contrôle rigoureux des admissions $(8,1 \%)$ et l'adoption de moyens de dépistage comme ceux mis en œuvre dans les hôpitaux $(7,1 \%)$

CONCLUSION : Les professionnels de la santé qui organisent des conférences en cette période de nouvelles maladies respiratoires peuvent tirer profit des réponses fournies par les participants au congrès durant la flambée de SRAS. Une communication claire sur les risques et les avantages possibles de la participation ainsi que sur la mise en place d'un arsenal complet de mesures de dépistage aideront à apaiser les craintes.
Severe acute respiratory syndrome (SARS) has caused signifSicant morbidity and mortality across the world. Toronto, Ontario, was among the first areas affected after the virus moved out of southern China in late February 2003 and began to spread internationally. The first patient with a probable case of SARS was identified in Toronto on February 23, 2003 (1). There were two clusters of SARS outbreaks in Ontario, with the first defined as cases identified before May 22, 2003, and the second cluster as those reported on or after May 22, 2003. The Canadian health toll from SARS was 438 cases (251 probable and 187 suspected) and 44 deaths, with the majority of cases occurring in the greater Toronto area (2). The SARS outbreak posed many psychological and occupational challenges to health care workers and patients (3). It also had a tremendous economic impact in Ontario, especially in Toronto (4). Anxiety surrounding SARS and the intense

Departments of Anaesthesia at ${ }^{1}$ The Hospital for Sick Children, ${ }^{2}$ University Health Network, ${ }^{3}$ Mount Sinai Hospital, and ${ }^{4}$ University of Toronto, Toronto, Ontario; ${ }^{5}$ Department of Psychology, and School of Kinesiology and Health Science, York University, Toronto, Ontario

Correspondence: Jennifer Stinson, Chronic Pain Program, Department of Anaesthesia, The Hospital for Sick Children,

555 University Avenue, Toronto, Ontario M5G 1X8. Telephone 416-813-6243, fax 416-813-7543, e-mail jennifer.stinson@sickkids.ca 
media coverage led to at least 95 conference cancellations or postponements (Toronto Tourism, personal communication).

The Canadian Pain Society (CPS) was poised to hold its annual meeting in Toronto on May 22 to 24, 2003. The projected attendance for this meeting was 500 to 600 delegates based on the previous numbers achieved at the Montreal meeting in 2001 (approximately 450 delegates). On April 23, 2003, the World Health Organization (WHO) issued an advisory against travel to Toronto. Given this decision, the CPS executive and conference planning committee decided to postpone the conference on April 23, 2003. Within a week of that decision, the WHO lifted the travel advisory to Toronto on the basis of data showing the number of SARS cases was declining. Following consultation with local experts, a decision was made on April 29, 2003, to proceed with the conference as originally planned. On May 14, 2003, Toronto was removed from the list of areas with recent local transmission. However, Toronto was placed back on the list on May 26, 2003, just two days after the end of the conference, when the virus surfaced in a second outbreak. It was not until, July 2, 2003, that the WHO officially removed Toronto from its list of areas with recent local transmission (5).

During this period, Ontario declared SARS a health emergency and used aggressive public health measures to try to control it. These public health measures included restricted hospital access, daily screening of hospital employees (such as temperature-taking, handwashing, report of respiratory symptoms and travel to affected areas or close contact with an individual diagnosed with SARS within the past 10 days), isolation precautions and even restricting health care professionals from attending meetings with other health care professionals. Despite a large epidemiological literature regarding disease outbreaks and the low risk of communitybased transmission, there was no information available to guide those planning the CPS meeting on how to screen and support delegates during the SARS crisis. For this reason, the conference planning committee decided to use a SARS screening tool developed by the University of Toronto Centre for Continuing Education (Appendix 1). This screening tool was e-mailed to speakers and delegates with a notice to read, print and bring the form to the conference for completion on the day of registration. It was also communicated that delegates were not to attend the conference if they had had any contact with SARS patients, symptoms of SARS or had travelled to a country listed on the WHO travel advisory. Conference delegates were screened once, upon initial registration.

The aims of the present study were to evaluate delegates' level of concern about attending the CPS conference in Toronto, to evaluate opinions on adequacy of screening measures instituted, and to evaluate reports of occupational and other consequences that resulted from attending the meeting. It is hoped that individuals planning future health care conferences and other continuing education endeavors in this era of new and emerging infectious diseases can apply what we have learned through this experience.

\section{Study design}

\section{METHODS}

A descriptive survey design was used to determine the impact and consequences of attending a health care conference during the SARS outbreak.

\section{Outcome measures}

A survey was developed to determine sociodemographical characteristics of delegates; whether SARS patients were being treated in their institutions; the perceived level of concern about attending the conference in Toronto; whether delegates considered cancelling their trip; the reasons for attending the conference despite concerns; the perceived adequacy of SARS screening at the meeting; suggestions for other screening procedures that might have been in place; whether delegates would have been more reassured had full screening procedures (as in Toronto-area hospitals) been implemented; the level of worry or stress about the SARS crisis during the conference; regrets about attending the conference in light of the second outbreak during the conference; the level of worry or stress about becoming infected with SARS following the conference; and work-related and other consequences of attending the conference. Questions were completed by ticking the appropriate box or using a 5-point Likert scale. Five of the questions allowed for open-ended responses (Appendix 2).

The survey was approved by the CPS executive and the Research Ethics Board at the University Health Network in Toronto. The survey was pretested for face validity before being administered to the sample group. The face validity of the survey was determined by having it reviewed by a variety of health professionals, including three physicians, two nurses, one psychologist and two consumer representatives. These health care professionals also determined that the survey was easy to read and complete.

On June 20, 2003, 27 days after the CPS conference ended, surveys were mailed to all 432 delegates and speakers that attended. The survey was mailed with a covering letter and a self-addressed stamped envelope for the return of the completed survey. As an additional incentive to return the completed survey, there was a random draw for a $\$ 100$ gift certificate. Of the 432 surveys sent out, 294 were returned, resulting in a response rate of $68 \%$. Completed surveys were returned over a three-month period (July 7 to September 23, 2003).

\section{Data analysis}

Descriptive statistics were used to analyze the data. Data were coded, scored, entered and analyzed using Statistical Package for the Social Sciences, version 11.0 (SPSS Inc, USA) (6). Participants' responses to the open-ended questions were transcribed verbatim and analyzed using iterative analysis.

\section{Description of participants}

\section{RESULTS}

The average age of respondents was 43.5 years $(\mathrm{SD}=11.4$, range 15 to 83 years). Two-thirds $(n=186)$ of the sample was female. Over one-half of the delegates were from medical $(\mathrm{n}=82)$ or nursing $(\mathrm{n}=78)$ professions. Other professionals included psychologists $(n=49)$, basic scientists $(n=30)$, pharmacologists $(n=7)$, physical therapists $(n=7)$, social workers $(n=3)$ and a variety of other professionals $(n=34)$ ranging from epidemiologists to policy consultants. One-half of the respondents worked in teaching $(n=108)$ or community-based $(n=41)$ hospitals, while one-quarter worked in university departments $(n=79)$ or other settings $(n=65)$ such as private pain clinics, rehabilitation facilities and pharmaceutical companies, as well as patient advocacy groups and nonprofit agencies. The vast majority ( $n=276$ or $94 \%$ ) of respondents were from Canada. Of those respondents from Canada, two-thirds lived in Ontario and $41 \%$ resided in the greater Toronto area. 
TABLE 1

Concerns regarding travelling to Toronto during the severe acute respiratory syndrome (SARS) outbreak to attend the Canadian Pain Society's annual meeting

\begin{tabular}{lc}
\hline Concern & $\begin{array}{c}\text { Number of } \\
\text { respondents } \\
\text { (\%) }\end{array}$ \\
\hline Exposure to SARS virus & $27(43.5)$ \\
Fear of transmitting the SARS virus to family, friends, co-workers & $11(17.7)$ \\
Concerned after second outbreak occurred & $8(12.9)$ \\
Being quarantined, preventing immediate return to work & $5(8.1)$ \\
Adequacy of screening at conference & $4(6.4)$ \\
Workplace prohibition about attending the conference & $2(3.2)$ \\
Not sure how the virus is transmitted & $2(3.2)$ \\
Getting SARS in public places (subway) & $2(3.2)$ \\
Fear of death from SARS due to age & $1(1.6)$ \\
\hline
\end{tabular}

One-quarter $(n=73)$ of the respondents worked in hospitals where SARS patients had been or were admitted at the time of the conference. Sixty-two of the respondents were speakers at the conference. Of the nonrespondents $(n=138)$, sex and geographical distribution were similar to the respondents.

Delegates and speakers attended either the education day on May 22, $2003(n=31)$, or the scientific meeting on May 23 and 24, $2003(n=124)$, while 138 delegates attended both. Approximately 60 delegates and 17 speakers decided not to attend and cancelled their registration for the meeting when they received notification that the meeting was proceeding as originally planned. The majority of cancellations were related to concerns regarding SARS.

Impact and consequences of attending the conference While one-half $(n=146)$ of the respondents were not concerned about travelling to Toronto due to the SARS crisis, the other half $(n=144)$ expressed some concern that ranged from mild concern $(n=84)$ to serious concern $(n=2)$. The major reasons cited for concern were being exposed to SARS or fear of transmitting it to family, friends or co-workers (Table 1). In addition, $27.2 \%(n=79)$ considered cancelling their trip to Toronto because of SARS. The major reasons for attending the conference, despite this concern, included desire for continuing education, quality of the program, decrease in the number of reported SARS cases before the meeting, and perceived minimal risk (Table 2 ).

Almost one-half of the delegates felt the screening measures instituted at the conference were very adequate $(n=95)$ or extremely adequate $(n=45)$. However, $4 \%$ of respondents felt it was inadequate and $10 \%$ somewhat adequate, while $38.4 \%$ were equivocal about the adequacy of the screening procedures. Several of these respondents commented that the screening measures were appropriate initially but needed to be more vigilant when the second outbreak occurred on May 23, 2003. Other screening measures that delegates $(n=99)$ felt should have been in place at the conference are outlined in Table 3. Twenty-eight percent of respondents $(n=82)$ would have been reassured if full screening measures had been instituted.

Three-quarters $(76.1 \%)$ of the delegates were not worried about becoming infected after attending the conference, while $10 \%$ expressed worry about SARS. Only $6 \%$ of the respondents
TABLE 2

Reasons for attending the conference despite concerns about severe acute respiratory syndrome

\begin{tabular}{lc}
\hline Reasons & $\begin{array}{c}\text { Number of } \\
\text { respondents } \\
\text { (\%) }\end{array}$ \\
\hline Continuing education and quality of program & $49(20.9)$ \\
Decrease in the number of reported cases & $39(16.6)$ \\
Perceived minimal risk & $39(16.6)$ \\
Communication from CPS/Planning committee with & $27(11.5)$ \\
links to Health Canada & \\
WHO travel ban lifted & $19(8.1)$ \\
Efforts to minimize risk/screening procedures in place & $17(7.3)$ \\
Live in Toronto & $16(6.8)$ \\
Conference was continuing as planned & $10(4.3)$ \\
Excessive media hype & $7(2.9)$ \\
Booked flight/time off work & $4(1.7)$ \\
Healthy & $3(1.3)$ \\
Institutional support to attend & $2(0.8)$ \\
Meeting was not taking place in a hospital & $2(0.8)$ \\
\hline
\end{tabular}

CPS Canadian Pain Society; WHO World Health Organization

TABLE 3

Other severe acute respiratory syndrome screening measures that respondents felt should have been instituted at the conference

\begin{tabular}{lc}
\hline Screening measures & $\begin{array}{c}\text { Number of } \\
\text { respondents (\%) }\end{array}$ \\
\hline Temperature taking & $29(32.2)$ \\
More vigilance in checking screening forms & $14(15.5)$ \\
No screening was necessary & $10(11.1)$ \\
Check forms on daily basis & $9(10)$ \\
More controlled entry & $8(8.8)$ \\
Same screening as in hospitals & $7(7.8)$ \\
Don't know what else could have been done & $6(6.7)$ \\
Hand washing gel & $4(4.4)$ \\
Not holding meeting in a hotel & $1(1.1)$ \\
Refuse entry to delegates from affected hospitals & $1(1.1)$ \\
Show proof of workplace & $1(1.1)$
\end{tabular}

had regrets about attending the conference. Finally, few reported any occupational $(n=1)$ or other $(n=8)$ consequences after attending the conference. The one respondent who reported an occupational consequence was called by her manager to ensure that she had no symptoms before returning to work. Two respondents reported that they had to be quarantined after the conference because one had visited a hospital affected in the second SARS outbreak and the other had learned that she had been in contact with a probable SARS case before attending the conference but had not been aware of it at the time of the conference.

Other consequences associated with attending the conference related to concerns voiced from co-workers, patients and family members about their attendance and fears that they would transmit the virus to them. A few delegates reported that they had had mild colds when they returned home and received comments from their co-workers that they should have gone into quarantine, while others commented on the 
stigma (eg, jokes, co-workers avoiding them) related to having been in Toronto. Many of the delegates who lived in Toronto commented that it was "daily life for them" and that SARS was probably more of a concern for those not from Toronto due to the exaggerated media reports regarding the SARS crisis. However, there were no significant differences in the level of concern, satisfaction with screening or stress between delegates who resided in Toronto and who resided outside Toronto.

\section{DISCUSSION}

We sought to describe the impact and consequences of attending the CPS's annual meeting in Toronto during the start of the second outbreak of SARS. One-half of the respondents expressed concern about travelling to Toronto for the conference. The major reasons for this concern included being exposed to SARS and fear of transmitting it to others upon their return home. The reasons for attending the conference despite this concern were a strong desire for continuing education, a decrease in the number of reported SARS cases and the perceived minimal risk associated with attending the meeting. Almost one-half of the respondents felt that the screening measures that were in place at the conference were adequate. However, $14 \%$ of the delegates felt that the screening measures were inadequate and $27 \%$ would have been more reassured had full screening measures been instituted.

Delegates at the conference worried about the possibility of becoming infected with SARS, as well as the possibility of transmitting the virus to loved ones, co-workers and patients. Despite the fact that a screening tool was used and information was provided to delegates in order to discourage attendance at the meeting if they had contact with actual or probable SARS cases, two exposed delegates attended the meeting. It was fortunate that other participants were not exposed to the SARS virus. Clear communication about the specific infectious disease and its mode of transmission, minimal risks of community exposure, and ensuring that adequate screening measures are in place are essential to allay the concerns of delegates during such outbreaks. The majority of delegates were not overly stressed or worried about attending the conference and they appeared to have benefited from accurate information regarding SARS that was provided by the CPS executive and conference organizers.

The screening measures used at this conference were chosen based on the fact that the first cluster of the SARS crisis appeared to be under control and resolving. Furthermore, several of the downtown hospitals in Toronto had stopped full screening precautions (eg, taking temperatures) by the time the meeting began. However, the second cluster of the SARS outbreak occurred during the meeting. Those respondents who felt we should have used more precaution when screening may have been referring to the second outbreak. More importantly, these delegates may choose not to attend future meetings if there is a similar outbreak because of their beliefs that there might be inadequate screening. This would result in a significant drop in attendance and revenue. While we considered increasing screening measures to include full screening (ie, rescreening, handwashing and temperature-taking), we decided against it primarily because local experts at the time did not recommend it.

There will always be individuals who decide not to attend meetings when crises such as the SARS epidemic strike. This self-selection bias likely skews the data in favour of lower reported stress levels and concerns about travelling to the affected region. Based on the responses from those in attendance, the data indicate that the majority of delegates believed the level of precaution we implemented was adequate. Tightening up the precautions to include full screening procedures would have resulted in an approximate $27 \%$ greater percentage of delegates being more reassured. Based on the results of this survey and the foregoing discussion, we would recommend implementation of full screening measures during such a crisis despite the expense and inconvenience.

The decision to hold or not to hold a major medical conference during an infectious outbreak of this magnitude is a complex one involving weighing the risks of possible exposure with the ongoing need to provide continuing medical education opportunities. In addition, the financial ramifications of cancelling such events need to be considered. Those organizing health care conferences need to be aware of the economical impact of outbreaks such as SARS because cancellation insurance does not cover infectious outbreaks. Cancellation insurance is available for those organizing medical conferences; however, SARS was an exclusion criterion for many insurance companies during the crisis.

\section{CONCLUSION}

Medical and other health care professionals planning conferences in this era of new respiratory diseases can benefit from understanding the responses of delegates who attend during outbreaks. While the majority of delegates felt that the precautions implemented were adequate, more than one-quarter would have been more reassured if full screening had been implemented. Our experience suggests that given similar circumstances, holding such a conference presents a low risk of infection to speakers and delegates; given the benefits of attending such a conference, this may outweigh any disadvantage of attendance. However, the organizers of future conferences will need to appraise individual circumstances on a case-by-case basis.

ACKNOWLEDGEMENTS: The authors thank members of the Canadian Pain Society executive who provided valuable input and support for this study.

FUNDING: Jennifer Stinson is supported by doctoral awards from the Canadian Nurses Foundation/The Hospital for Sick Children Foundation/Canadian Institutes of Health Research and by a Clinician Scientist Training Award from The Hospital for Sick Children. Joel Katz is supported by a Canada Research Chair in Health Psychology at York University, Toronto, Ontario.

\section{REFERENCES}

1. Health Canada. Summary of severe acute respiratory syndrome (SARS) cases. <http://www.who.int/csr/sars/country/en/country2003_08_15.pdf> (Version current at June 1, 2004).

2. Health Canada. Canadian SARS Numbers, Ottawa: Health Canada. <http://www.hc-sc.gc.ca/pphb-dgspsp/sars-sras/cn-cc/20030903_e.html> (Version current at June 1, 2004).

3. Maunder R, Hunter J, Vincent L, et al. The immediate psychological and occupational impact of the 2003 SARS outbreak in a teaching hospital. CMAJ 2003;168:1245-51.

4. Mackay B. As SARS toll climbed, so did economic cost to Toronto. CMAJ 2003;168:1456.

5. World Health Organization. Communicable Disease Surveillance \& Response Update 93 - Toronto removed from list of areas with recent transmission. <http://www.who.int/csr/don/2003_07_02/en/> (Version current at June 1, 2004). 


\section{APPENDIX 1}

\section{SEVERE ACUTE RESPIRATORY SYNDROME (SARS)}

\section{SIMPLIFIED SCREENING TOOL FOR HEALTH PROFESSIONALS}

This screening tool has been adapted from the form devised for use by all Ontario health care settings. The form must be completed by all persons entering this meeting who are health professionals active in acute ambulatory or in-patient care.

\section{SECTION A:}

1. Have you had unprotected contact with a person with SARS in the last 10 days?

Yes Quarantine: Public Health notified

No

2. In the last ten days, have you worked in a level III SARS unit? (Level III definition: unprotected SARS exposure with transmission to health care workers and/or patients with further transmission from infected health care workers or patients to others within the hospital)

3. In the last ten days, have you travelled to China, Hong Kong, Singapore, Hanoi or a similar SARS-affected area?

SECTION B: Are you experiencing ANY of the following symptoms?

$\square$ Myalgia (muscle aches) OR

$\square$ Malaise (severe tiredness or unwell) $\mathbf{O R}$

$\square$ Severe headache (worse than usual or atypical) OR

$\square$ Cough (onset within 7 days) OR

$\square$ Shortness of breath (worse th an what is normal for you) $\mathbf{O R}$

$\square$ Feeling feverish, or have had a fever in the last 24 hours

If the response is YES to any of the above, then the individual should NOT attend the meeting/session and should follow applicable public health directives.

\section{Name of Participant/Registrant:}

Signature:

Date: 


\section{APPENDIX 2}

\section{SARS Survey}

\section{Impact of the SARS crisis and screening on a medical conference in Toronto: Survey of Delegates}

We are interested in learning about the impact of the SARS outbreak and the usefulness of the screening procedures in place at the Canadian Pain Society (CPS) Conference in Toronto on May 22-24, 2003. As a delegate or speaker at the meeting, your responses to this questionnaire are very much appreciated. Your confidential responses will only be reported in aggregate form.

1. How old are you (years)?

2. What is your sex? [] Male [] Female

3. What profession do you belong to? (tick only one)
[] Medicine
[] Psychology
[] Physical Therapy
[] Nursing
[] Social Work
[] Pharmacy
[] Basic Scientist
[] Clinical Scientist
[] Other, please specify:

4. In what city, province/state and country do you live?

\section{City}

Province/State
Country

5. Describe your workplace: [] Community Hospital [] Teaching Hospital

[] Other (please specify):

6. Have any SARS patients been admitted to your workplace? [] No [] Yes

7. Were you a speaker or delegate at the CPS meeting? (tick only one)
[] Speaker
[]
Delegate

8. Indicate which day(s) you attended the CPS meeting (tick one or both items):

[] Pain Education Day (May 22) [] Scientific Program (May 23 \& 24)

9. Please indicate your level of concern about traveling to Toronto for the recent

CPS conference because of SARS (circle one item from 1 to 5).

Not at all concerned

$$
1
$$

Fairly concerned

3
Seriously concerned

4

\section{5}

Please list your concerns, if any:

10. Did you consider canceling your trip?

[] No [] Yes

11. What encouraged you to attend in light of the current SARS situation? 
12. What did you think of the SARS screening procedures in place at the conference (circle one item from 1 to 5)?

Not at all adequate

Equivocal

1

2
Extremely adequate

4

Please list what other screening procedures should have been in place at the conference:

13. How worried or stressed were you about the SARS crisis during the conference?

Not at all Equivocal

Very

$\begin{array}{lllll}1 & 2 & 3 & 4 & 5\end{array}$

14. After your trip in light of the recent SARS outbreak, did you had any regrets about attending the conference? [] No [] Yes

15. How worried or stressed were you about the SARS crisis in the ten days after the conference?

Not at all

Equivocal

Very

1

2

3

4

5

16. On your return home, were there any occupational consequences that followed from your attending the conference (eg, quarantine)? [] No [] Yes

- If yes, please specify:

17. On your return home, were there any other consequences associated with attending the conference (eg, being avoided by others)? [] No [] Yes

- If yes, please specify:

18. Please indicate the date you have completed this form:

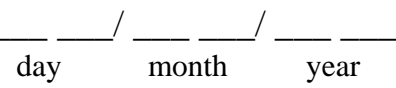

19. Please add any other comments you feel would be important to consider

We are interested in the extent to which you are affected/stressed by the experience of having attended the meeting during the SARS outbreak. We would be grateful for your help with this and ask that you complete the 15-item survey we have attached. Please mail back this form and the completed survey to us in the self-addressed, stamped envelop we have provided.

\section{THANK YOU}




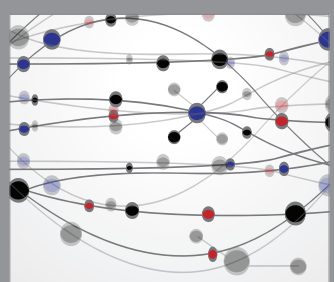

The Scientific World Journal
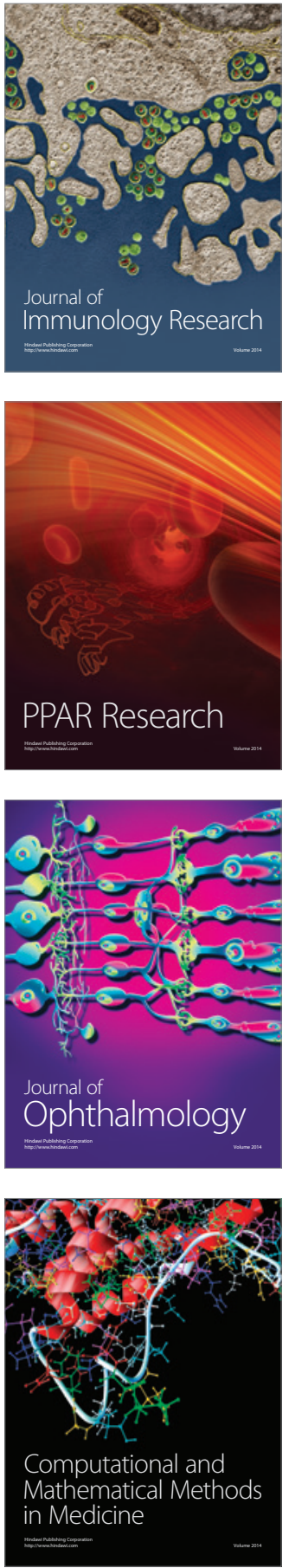

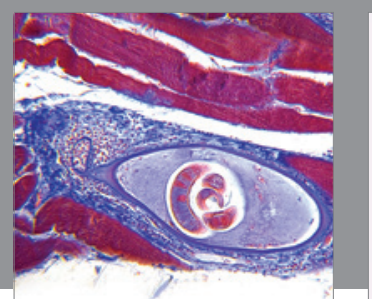

Gastroenterology Research and Practice

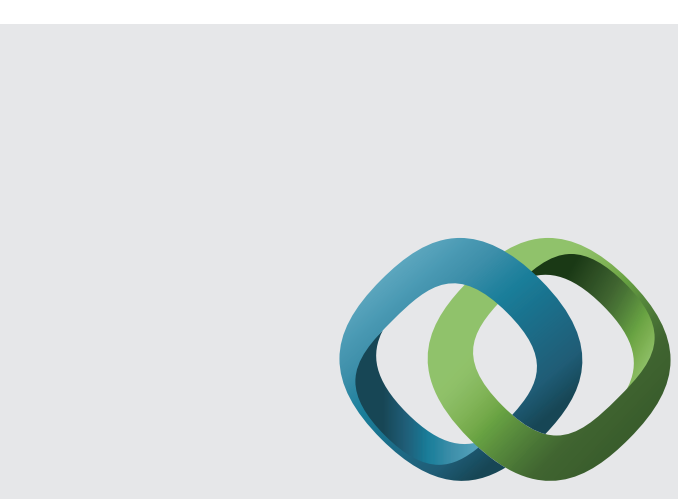

\section{Hindawi}

Submit your manuscripts at

http://www.hindawi.com
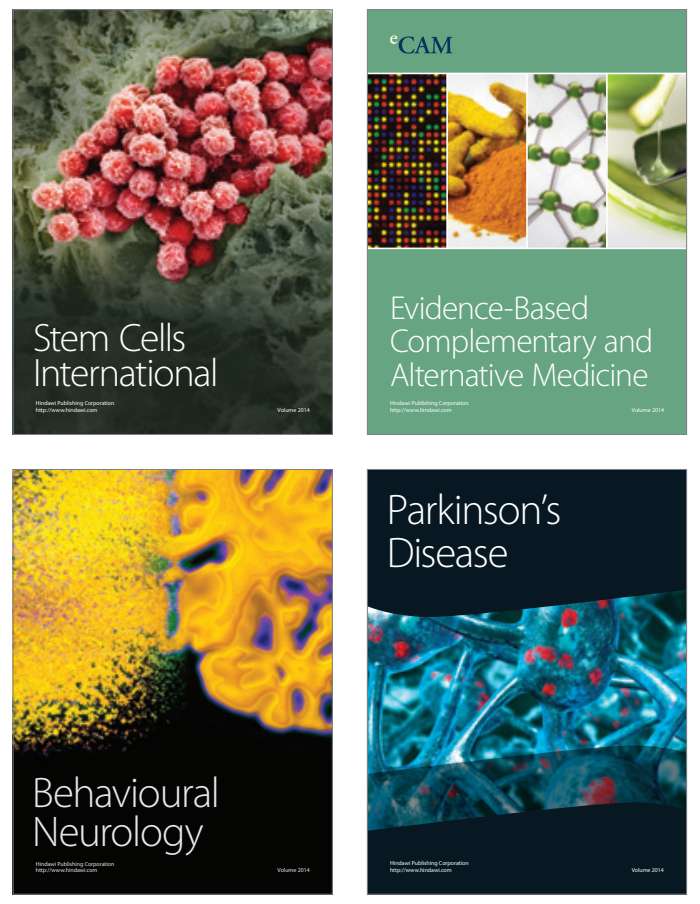
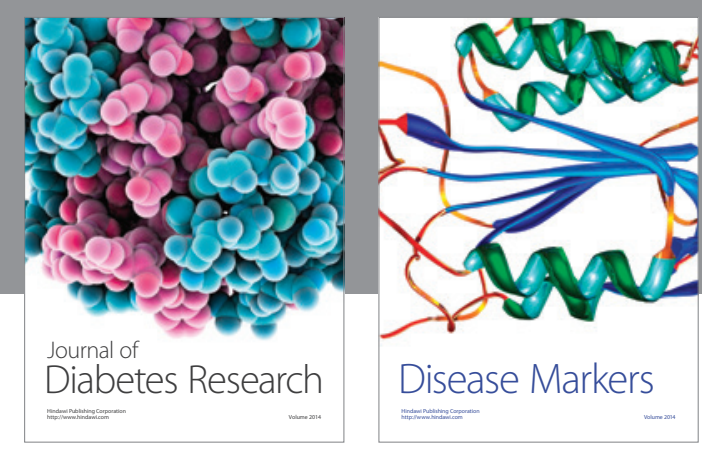

Disease Markers
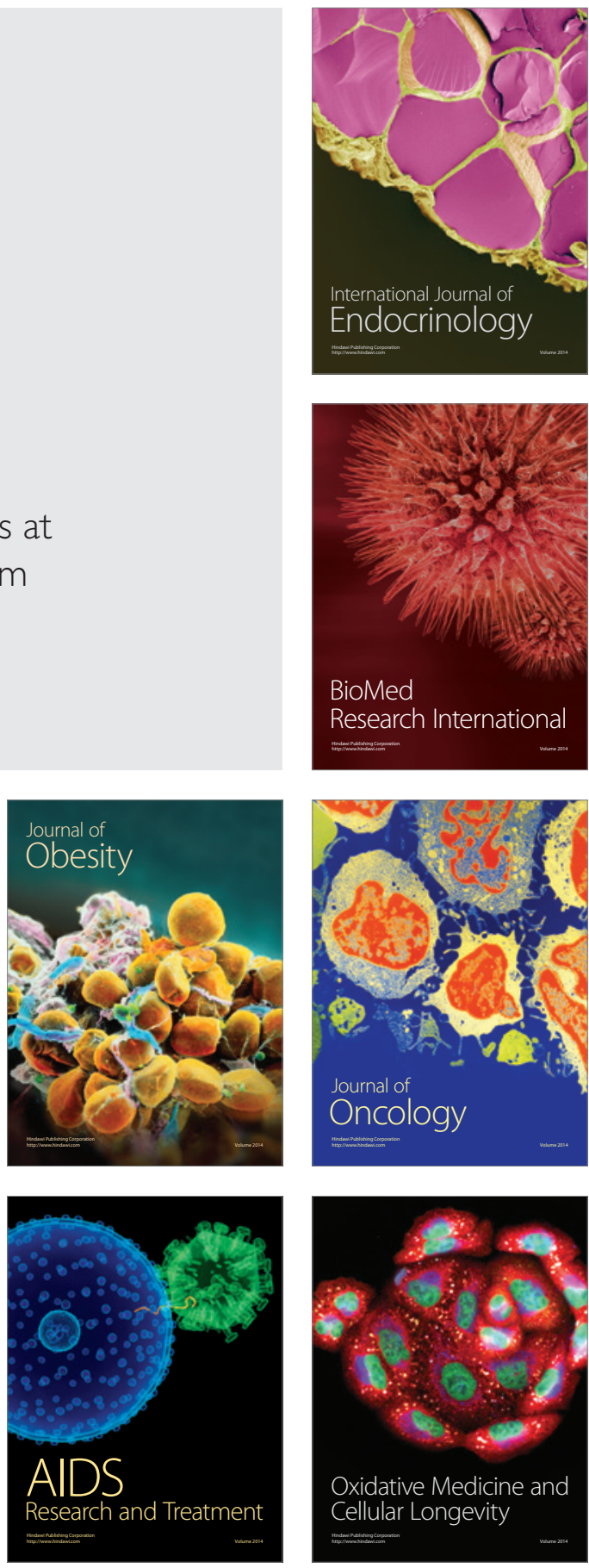